\title{
Article \\ Neurotoxic Potential of Deoxynivalenol in Murine Brain Cell Lines and Primary Hippocampal Cultures
}

\author{
Christiane Kruse Fæste ${ }^{1, *(\mathbb{D})}$, Anita Solhaug ${ }^{1}\left(\mathbb{D}\right.$, Marion Gaborit $^{2}$, Florian Pierre ${ }^{2, \dagger}$ and Dominique Massotte ${ }^{2, *(\mathbb{D})}$ \\ 1 Toxinology Research Group, Norwegian Veterinary Institute, 1433 Ås, Norway; anita.solhaug@vetinst.no \\ 2 Centre de la Recherche Nationale Scientifique, Institut des Neurosciences Cellulaires et Intégratives, \\ University of Strasbourg, 67000 Strasbourg, France; gaborit@inci-cnrs.unistra.fr (M.G.); \\ f.pierre@ibmc-cnrs.unistra.fr (F.P.) \\ * Correspondence: christiane.faste@vetinst.no (C.K.F.); d.massotte@unistra.fr (D.M.); \\ Tel.: +47-47-753-488 (C.K.F.); +33-388-456-652 (D.M.) \\ † Present Address: Florian Pierre, Institut de Biologie Moléculaire et Cellulaire, 67084 Strasbourg, France.
}

Citation: Fæste, C.K.; Solhaug, A.; Gaborit, M.; Pierre, F.; Massotte, D. Neurotoxic Potential of

Deoxynivalenol in Murine Brain Cell Lines and Primary Hippocampal Cultures. Toxins 2022, 14, 48. https:// doi.org/10.3390/toxins14010048

Received: 18 December 2021

Accepted: 6 January 2022

Published: 10 January 2022

Publisher's Note: MDPI stays neutral with regard to jurisdictional claims in published maps and institutional affiliations.

Copyright: (C) 2022 by the authors. Licensee MDPI, Basel, Switzerland. This article is an open access article distributed under the terms and conditions of the Creative Commons Attribution (CC BY) license (https:// creativecommons.org/licenses/by/ $4.0 /)$.

\begin{abstract}
Chronic exposure to the mycotoxin deoxynivalenol (DON) from grain-based food and feed affects human and animal health. Known consequences include entereopathogenic and immunotoxic defects; however, the neurotoxic potential of DON has only come into focus more recently due to the observation of behavioural disorders in exposed farm animals. DON can cross the blood-brain barrier and interfere with the homeostasis/functioning of the nervous system, but the underlying mechanisms of action remain elusive. Here, we have investigated the impact of DON on mouse astrocyte and microglia cell lines, as well as on primary hippocampal cultures by analysing different toxicological endpoints. We found that DON has an impact on the viability of both glial cell types, as shown by a significant decrease of metabolic activity, and a notable cytotoxic effect, which was stronger in the microglia. In astrocytes, DON caused a G1 phase arrest in the cell cycle and a decrease of cyclic-adenosine monophosphate (cAMP) levels. The pro-inflammatory cytokine tumour necrosis factor (TNF)- $\alpha$ was secreted in the microglia in response to DON exposure. Furthermore, the intermediate filaments of the astrocytic cytoskeleton were disturbed in primary hippocampal cultures, and the dendrite lengths of neurons were shortened. The combined results indicated DON's considerable potential to interfere with the brain cell physiology, which helps explain the observed in vivo neurotoxicological effects.
\end{abstract}

Keywords: astrocytes; deoxynivalenol; microglia; mouse; mycotoxin; primary hippocampal cultures

Key Contribution: Exposure to low levels of deoxynivalenol affects astrocytes; microglia and neuron physiology. Symptoms of neuroinflammation are observable already before apoptosis is initiated.

\section{Introduction}

The mycotoxin deoxynivalenol (DON) (Figure 1) occurs with high a prevalence in grain-based products worldwide [1]. Consequently, the maximum allowed levels in food and feed have been implemented by national and international authorities, based on toxicity studies and risk assessments, as performed by the European Food Safety Authority (EFSA) [2-4]. Compliance with the regulations generally prevents incidences of acute DON intoxication, but low-level chronic exposure in humans and animals is still common. The monitoring of urinary biomarkers of DON allows evaluating the amounts of ingested DON [5]. Surveys performed in different countries have shown that the mean chronic dietary exposure, especially in children, often exceeds the established tolerable daily intake (TDI) of $1 \mu \mathrm{g} / \mathrm{kg}$ body weight (bw) for the sum of DON and its derivatives [6,7]. 


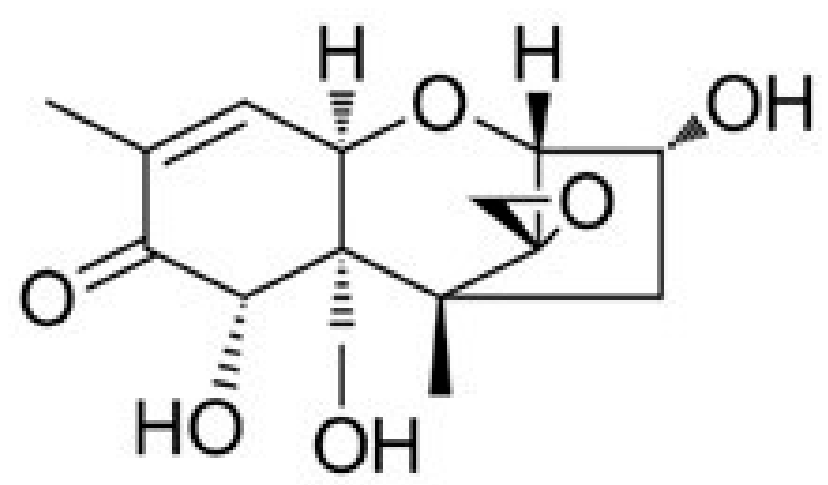

Figure 1. Molecular structure of deoxynivalenol (DON).

Several in vivo studies have shown that chronic low-level DON exposure can lead to entereopathogenic, immunotoxic, and neurotoxic effects, resulting in negative changes in gut health, immunological resilience, and behaviours [8-10]. DON-induced neurotoxicity has come into focus only recently, triggered by observed deviant behaviour traits, such as aggressiveness, anxiety, and increased locomotor activity in mice, rats, pigs, poultry, and mealworm beetle larvae after chronic exposure to feedborne DON at concentrations ranging from 0.1 to $25 \mathrm{mg} / \mathrm{kg}$ [10-14]. DON can cross the blood-brain barrier and directly modulate brain activity $[15,16]$. Known consequences of chronic low-dose DON exposure include the disturbance of catecholamine neurotransmitter levels such as dopamine, norepinephrine, and serotonin in the hypothalamus and cortex of different animal species [17-19]. Furthermore, pro-inflammatory cytokines (interleukin (IL)-1 $\beta$, IL-6, tumour necrosis factor (TNF)- $\alpha$ ), and the transcription factor c-Fos were increased in specific brain regions, including the nucleus accumbens, paraventricular nucleus of the thalamus, and dorsal tenia tecta after repeated exposure to low DON concentrations [9,10,12,20-23]. Feeding piglets with $>1.3 \mathrm{mg}$ DON $/ \mathrm{kg}$ feed for 60 days disrupted the cerebral calcium homeostasis, increased lipid oxidation, and decreased the activities of the anti-oxidative enzymes glutathione peroxidase and superoxide dismutase [23]. In rats treated with $>0.2 \mathrm{mg} D O N / \mathrm{kg} b w$ for 42 days, a reduction of the gliocytes and neurons was observed in the myenteric plexus of the jejunum [24].

Several in vitro assays have been performed to determine the underlying molecular mode of actions for the detected physiological changes caused by DON. The mycotoxin is water-soluble and uncharged at physiological $\mathrm{pH}$. However, studies in a cell line, derived from colon cells (Caco-2) have shown that DON can pass through cell membranes and reach the cytosol as a substrate of ATP-binding cassette transporters (ABC transporters) [25]. Intracellularly, one primary action of DON is inhibition of the protein synthesis by binding to the $60 \mathrm{~S}$ ribosomal subunit and decreasing peptidyl transferase capacities, leading to activation of mitogen-activated protein kinase (MAPK) and subsequent apoptosis [26]. When DON-triggered effects on transcription and translation reactions were investigated in mouse macrophages by phosphoproteomics, changes in the phosphorylation patterns of almost 200 proteins were observed, including those involved in proliferation, cell cycle, differentiation, and cytoskeleton organisation [27]. Apoptosis through the mitochondrial pathway was prompted by the activation of caspase-3 leading to DNA fragmentation in PC12 cells of rat adrenal medulla [28]. Furthermore, DON was found to cause oxidative stress and damage in chicken embryo fibroblast DF-1 cells [29].

The consequences of exposing macrophages to low DON levels have been investigated in several in vitro studies, showing an increased production and secretion of inflammatory cytokines such as IL- $1 \beta$, IL- 6 , and TNF- $\alpha$, as well as changes in the surface expression of cell signalling and adhesion molecules as a main outcome [30-34]. Further reactions included the increase of hydrogen peroxide and nitric oxide (NO) levels in the presence of immunostimulants, e.g., lipopolysaccharide (LPS) or interferon [29,30,33,35]. In vivo, macrophage-driven inflammation has been identified as an early reaction of chronic low- 
level DON exposure both in the gastrointestinal tract and brain of mice, rats, chicken, and pigs $[9,12,18,20,36]$, demonstrating the predictive value of the cell toxicity studies [37].

Interestingly, most assays that elucidate consequences of DON exposure at the cellular level have been performed in intestinal, skin, kidney, or peripheral blood cells. Reports on effects in brain cells are scarce, although relevant DON concentrations can be measured in the brain already 5 min after oral uptake [36]. Furthermore, it has been shown that DON induced apoptosis in a hippocampal cell line from a pig, by triggering the inflammationrelated MAPK signalling pathway [15]. Moreover, in rat primary cortical glial cells and immortalized human microglial C13NJ cells, low DON concentrations led to the production of reactive oxygen species from lipid oxidation and NO production [29,35]. Glial cells, including astrocytes and microglia, are essential for maintaining brain homeostasis and functionality as astrocytes provide nutrients and structural support, and microglia supply for the main immune defence in the central nervous system [38]. Disturbance of the physiological balance by DON could be one of the reasons behind the observed in vivo neurotoxicity [39].

In the present study, we have, therefore, focussed on investigating DON-induced effects on murine astrocytes and microglial cell lines, as well as on primary brain cells from young mice, while studying relevant endpoints of toxicity in several cytotoxic and functional tests.

\section{Results and Discussion}

\subsection{Viability of Mouse Astrocytes and Microglia}

The viability of both glial cell types in the presence of $\mu$ molar DON concentrations was assessed by measuring the metabolic activity using the Alamar blue assay and by determining the general cytotoxicity using the Celltox Green assay [40]. Results of the Alamar Blue assay reflect the general impact of a substance on the cells viability, independently of the actual mode of action, which e.g., could be connected to reduced cell proliferation, reduced metabolism, and/or increased cell death. On the other hand, the Celltox Green assay uses the influx of a non-toxic fluorescent dye into the cells with impaired membrane integrity as a measure for general cytotoxicity.

Both the murine astrocytes and microglia showed a significant decrease of metabolic activity already after exposure to $0.8 \mu \mathrm{M}\left(\mathrm{IC}_{50} 5.8 \mu \mathrm{M}\right)$ and $1.6 \mu \mathrm{M}$ DON $\left(\mathrm{IC}_{50} 7.2 \mu \mathrm{M}\right)$ for $24 \mathrm{~h}$, respectively (Figure 2a). The microglia were notably more sensitive in the cytotoxicity assay than the astrocytes, with significant differences to the untreated control at $3.1 \mu \mathrm{M}$ DON for microglia and at $6.3 \mu \mathrm{M}$ DON for astrocytes after exposure for $24 \mathrm{~h}$ (Figure $2 \mathrm{~b}$ ). A distinct dissimilarity between the nervous cell types was observable from the further progression of the concentration-cytotoxicity curve, leading to a wide sensitivity gap at $25 \mu \mathrm{M}$.

Considering the results of the Alamar Blue and the Celltox Green tests together, it appeared that the viability decrease of the microglia resulted largely from DON-induced cytotoxicity at concentrations above $3.1 \mu \mathrm{M}$, whereas the rather steep drop in viability observed for the lower DON levels was probably caused by reduced metabolic activity. In the astrocytes, the cytotoxic effects were much less pronounced, as similarly seen at higher DON concentrations, so that they alone are not sufficient to explain the detected viability loss.

A decrease of cell viability connected to a reduced metabolic activity from exposure to DON has previously been determined in human colorectal adenocarcinoma (Caco-2) cells at $10 \mu \mathrm{M}$ [41], in dog kidney (MDCKII) cells at $4 \mu \mathrm{M}$ [25], in pig pulmonary alveolar macrophages (PAM) at $1 \mu \mathrm{M}$ [30], in human (Jurkat T cells or acute monocyte leukaemia cells (THP-1)), and mouse (RAW 264.7) macrophages at $0.8 \mu \mathrm{M}[31,32,42]$. The differences in the measured sensitivities may reflect that different tests, e.g., Alamar Blue or Thiazolyl blue tetrazolium bromide (MTT), were used to measure the effect of DON on the cell metabolic activity, but could also originate from an increased vulnerability in cells with high metabolic activity. The astrocytes have a considerable high metabolism, due to their 
role in nutrient provision, and thus damage repair in the brain might significantly be affected by DON (Figure 2a), while the cells were more resistant to DON-initiated processes causing membrane damage (Figure 2b). As previously shown in human epithelium cells of the small intestine (HT-29-D4), DON can disturb the nutrient absorption by interacting with transmembrane transporters, such as the D-glucose/D-galactose sodium-dependent transporter (SGLT-1), D-fructose transporter (GLUT-5), or the D-glucose transporter 2 (GLUT-2) [43]. A similar interference could be supposed to impair transport mechanisms across the astrocyte cell membrane, namely via the D-glucose transporter GLUT-1 [44]. DON at concentrations of $1 \mu \mathrm{M}$ or higher has been shown to prevent astrocytes from reabsorbing the neurotransmitter glutamate [35].

a)

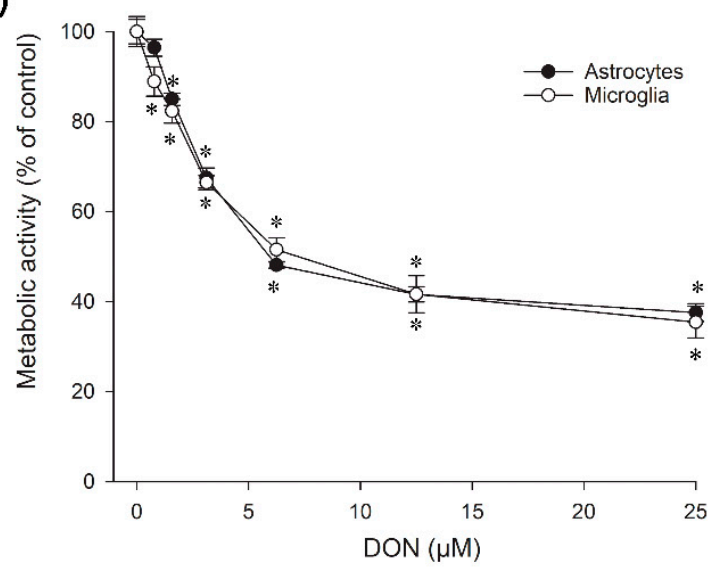

b)

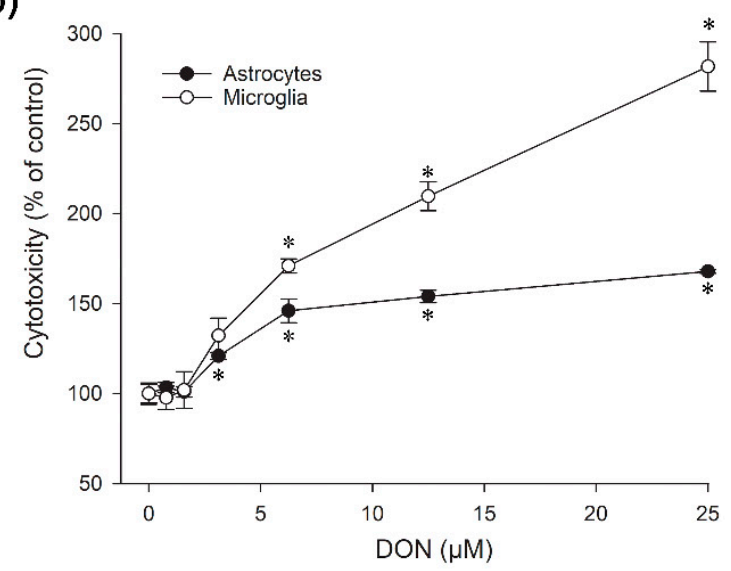

Figure 2. Effect of DON on the viability of astrocytes and microglia after $24 \mathrm{~h}$ of exposure; (a) Metabolic activity as measured in the Alamar Blue assay; (b) Cytotoxicity as determined in the Celltox Green assay. The data represent the mean \pm SEMs of four independent experiments performed in triplicates. Significant differences $(p<0.05)$ as compared to the control are indicated with asterisks $\left(^{*}\right)$.

Our results showing a disparity in DON sensitivity between murine astrocytes and microglia in the cytotoxicity assay agreed well with previous reports. When primary rat microglia and astrocytes were exposed to DON for $48 \mathrm{~h}, \mathrm{IC}_{50}$ of $0.6 \mu \mathrm{M}$ versus $31 \mu \mathrm{M}$ were measured, and the exposure of immortalised human microglial (C13NJ) and astrocytic (STTG-1) cells led to $\mathrm{IC}_{50} 4.1 \mu \mathrm{M}$ versus $50 \mu \mathrm{M}$ [35]. A conclusive explanation for the increased DON sensitivity of the microglia has not been offered yet, but it could be connected to the toxin's ribotoxic activity, since the same was found for other agents with a congruous mode of action [33,35]. Glial reactivity is regarded as the key indicator for brain inflammation and as an early biomarker of neurotoxicity [45,46]. Tests involving other monocytes/macrophages demonstrated cytotoxicity at similar DON concentrations, resulting in significant effects at $2 \mu \mathrm{M}$ in human monocyte leukaemia cells (THP-1), measured by the same Celltox Green assay as used in our study [31]. Alternative test methods for cytotoxicity led to the determination of $\mathrm{IC}_{20}$ at $0.4 \mu \mathrm{M}$ DON in primary porcine macrophages [30] and a significance at $0.2 \mu \mathrm{M}$ in mouse macrophages (RAW 264.7) [47]. A plausible explanation for the detected differences in DON-related cytotoxicity between astrocytes and microglia could be the much higher proliferation rate of the astrocytes, which makes them more robust due to higher turnover than the slow-proliferating microglia.

\subsection{Cell Cycle Analysis in Astrocytes}

Looking for possible causes for the somewhat low DON-induced cytotoxicity in the murine astrocytes, we next studied potential effects disturbing the normal sequence of the cell cycle. Healthy, dividing cells synthesise RNA and proteins during the post-mitotic G1 phase, duplicate the DNA in the $S$ phase, increase the production of RNA and proteins in the G2 phase, and undergo mitosis in the M phase. To avoid the generation of cells 
with damaged or abnormal DNA, the cell cycle progression in mammalian cells is under strict control by numerous factors, including mediator, effector, and regulator proteins, e.g., phosphokinases, transcription factors, and histones [48]. The arrest or delay of the cell cycle provides time for DNA repair or the initiation of apoptosis to prevent the proliferation of malign copies. Accurate transition from the G1 phase to the $S$ phase is thus a crucial point in the cell cycle.

We observed a significant increase of cells in the G1 phase after $24 \mathrm{~h}$ exposure to 5 or $10 \mu \mathrm{M}$ DON, accompanied by the respective decrease of cells in the S-phase (Figure 3a,b). The ratio of cells present in the G2/M phase was apparently not substantially changed. However, a general slow-down in proliferation was observed already at $1 \mu \mathrm{M} \mathrm{DON}$ (data not shown).

a)

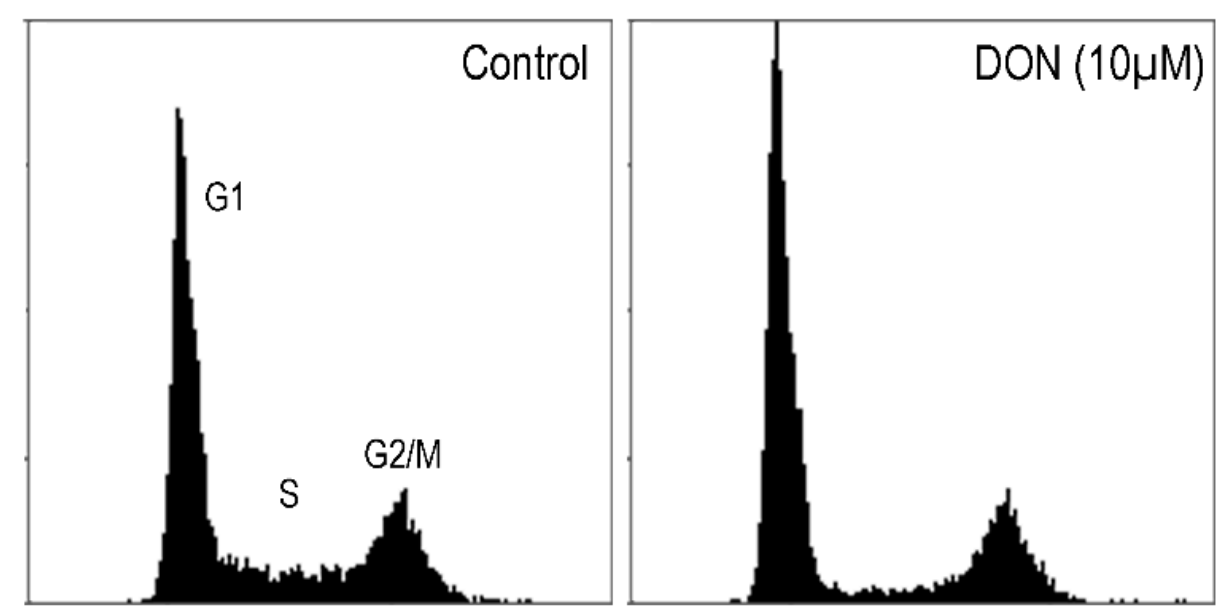

b)

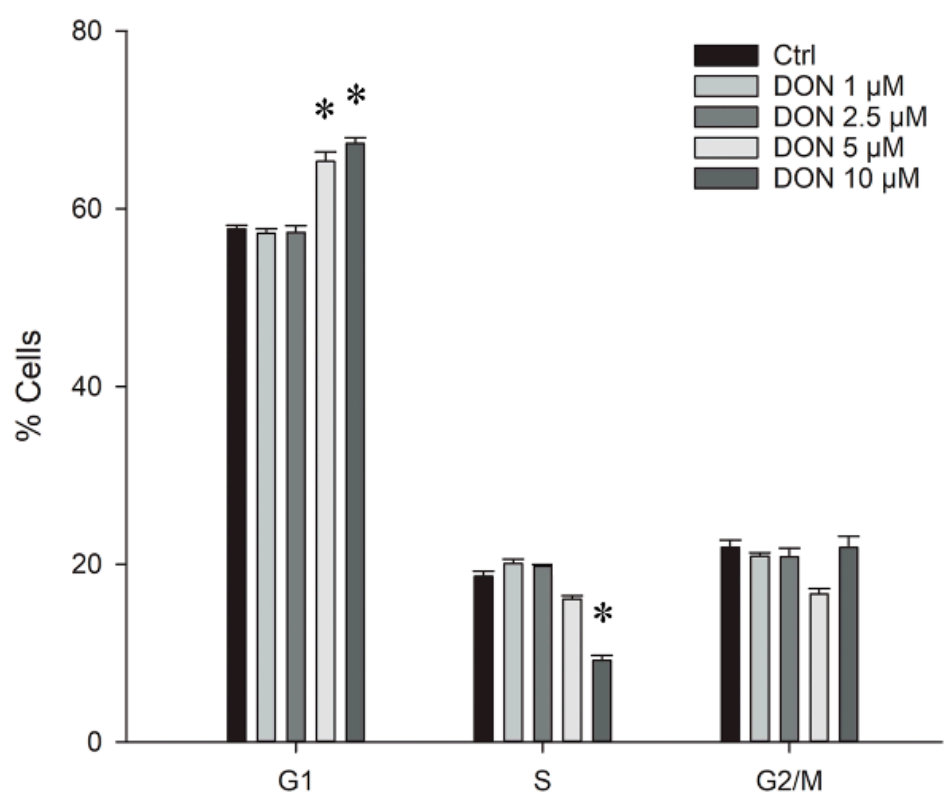

Figure 3. (a) Typical distribution of murine astrocytes after $24 \mathrm{~h}$ exposure to 0 or $10 \mu \mathrm{M} \mathrm{DON}$ in different phases of the cell cycle as measured by flow cytometry; (b) Ratios of the cell population in G1, $\mathrm{S}$, and G2/M phases after exposure to different DON concentrations for $24 \mathrm{~h}$. The data are representatives of two independent experiments and are expressed as mean \pm SD of four replicate incubations. Significant differences $(p<0.05)$ as compared to the control are indicated with asterisks $\left(^{*}\right)$. 
The DON-induced G1 arrest detected in the astrocytes in this study pointed at a substantial disturbance of on-going cellular processes; however, the underlying mechanism is unclear. Considering the ribotoxic activity of DON, interference with protein translation, activation of the MAPK pathway, and the subsequent disruption of regulatory functions that initiate the transition to the $S$ phase could have caused the observed effect. Comparable to our findings, G1 arrest by low-level DON exposure for $24 \mathrm{~h}$ as well as the initiation of apoptosis has previously been described in human monocytes (THP-1) [31], mouse macrophages (J774A.1) [49], rat intestinal epithelia (IE-6) [50], and primary pig endometrial cells [51]. For human hepatocarcinoma cells (HepG2) [52] and chicken embryo fibroblasts (DF-1) [29], a significant increase in G1 was determined after exposure to $0.6 \mu \mathrm{M}$ and $1.7 \mu \mathrm{M}$ DON, respectively, whereas levels above $1.2 \mu \mathrm{M}$ and $3 \mu \mathrm{M}$, respectively, led to a significant rise in the G2/M cell population and decline of cells in the S-phase accompanied by substantial cell death.

A similar change was found in intestinal pig cells (IPEC-J2), where exposure to $6.8 \mu \mathrm{M}$ DON for $24 \mathrm{~h}$ resulted in the increase and decrease of cell numbers in the G1 and S phase, which was reversed and complemented with an increase of G2/M cells after incubation for $48 \mathrm{~h}$ and $72 \mathrm{~h}$ [53]. In contrast, incubation of mouse macrophages (RAW264.7) with 1 to $4 \mu \mathrm{M}$ DON for $12 \mathrm{~h}$ blocked the cell cycle immediately in the G2/M phase [32], which was also observed in human intestinal epithelia (HCT-116) after exposure to 0.8 to $3.4 \mu \mathrm{M}$ for $48 \mathrm{~h}$ [54]. Considering the different reports, the detected changes appeared to be influenced by a combination of DON concentrations, exposure periods, and sensitivity of the respective cell lines. Since the orderly organisation of the cell cycle depends on multifactorial coordination, the identification of the decisive part would be challenging [48]. Nevertheless, a recent transcriptomic study of Caco-2 cells that had been exposed to $0.5 \mu \mathrm{M}$ DON for $24 \mathrm{~h}$ revealed changes in the expression of cell cycle-related genes as one of the top five affected pathways, creating the basis for more in-depth target analyses [55].

\subsection{Cytokine Secretion in Microglia}

Based on the results of the cytotoxicity assay we investigated in a next step, whether DON-stimulated cytokine expression occurred in the murine astrocytes and microglia. While neither TNF- $\alpha$ nor IL-1 $\beta$ secretion were detectable in astrocytes after $24 \mathrm{~h}$ incubation (data not shown), dose-dependent TNF- $\alpha$ secretion was measurable in the microglia at non-cytotoxic DON concentrations (Figure 4). Interestingly, IL-1 $\beta$ secretion was not found, not even after pre-incubation with the immunostimulant LPS for $3 \mathrm{~h}$ (data not shown), which previously had led to increased synergistic release of IL- $1 \beta$ and TNF- $\alpha$ at low DON concentrations in a human acute monocyte leukaemia cell line (THP-1) [56].

Transcriptomic analysis of primary porcine macrophages incubated with $0.5 \mu \mathrm{M} D \mathrm{DN}$ showed that the expression of TNF- $\alpha$ mRNA peaked after $3 \mathrm{~h}$, and TNF- $\alpha$ protein in the cell supernatant was elevated until $48 \mathrm{~h}$ [30]. Similarly, IL-1 $\beta$ mRNA was highest after $3 \mathrm{~h}$ DON exposure, but IL-1 $\beta$ protein declined rapidly and was at $24 \mathrm{~h}$ almost at the same level as at $0 \mathrm{~h}$. The additional use of LPS made no difference, which was congruent with our results determined in the murine microglia. The regulation of cytokine profiles in the microglia could be a means of adjusting the progression of neuroinflammation. Moreover, it has been suggested that astrocytes might be able to attenuate microglia activation [45]. 


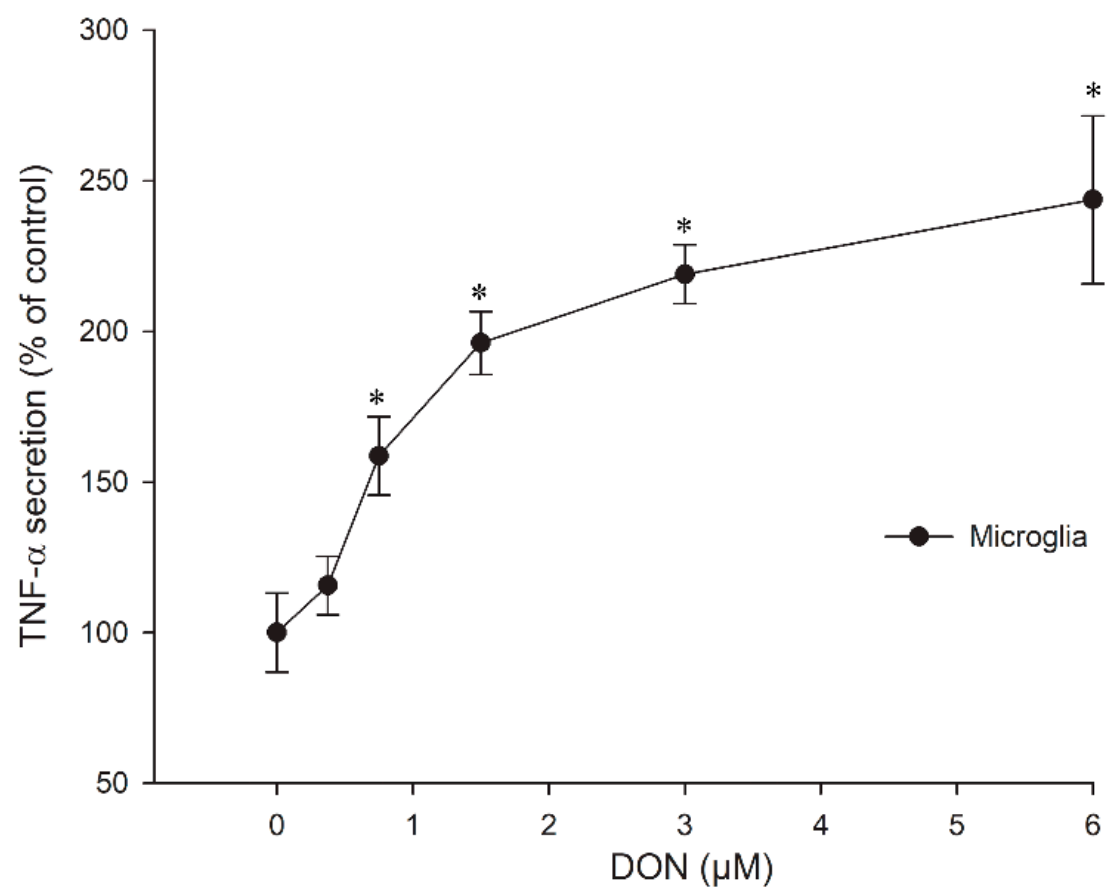

Figure 4. TNF- $\alpha$ secretion in microglial cells after $24 \mathrm{~h}$ exposure to different DON concentrations. The data represent the mean \pm SEM of four independent experiments and are normalised to the control at $100 \%$. Significant differences $(p<0.05)$ as compared to the control are indicated with asterisks $\left(^{*}\right)$.

\section{4. cAMP Levels}

Cyclic-adenosine monophosphate (cAMP) is part of intracellular signal transmission pathways, controlling the activity of protein kinase $\mathrm{A}$ as a co-factor and thus regulating the subsequent phosphorylation of multiple substrates that are relevant in stress response, cell proliferation, and development. Neurotoxic chemicals have been shown to affect cAMP levels in astrocytes in vivo [57] and to impair cAMP-dependent astrocytic differentiation in vitro [58]. Moreover, the stimulation of cAMP-prevented neuroinflammation in primary rat astrocytes by significantly reducing the LPS-inducible nitric oxide synthase (iNOS)/NO release [59].

In the present study, we have, therefore, investigated if exposure to DON could result in changes in the cAMP level in mouse glial cells. The assay revealed that the intracellular cAMP concentrations were affected in astrocytes already after incubation for $1 \mathrm{~h}$ (Figure 5), whereas no change was observable in the microglia after this time (data not shown). In contrast, $4 \mu \mathrm{M}$ of the positive control substance forskolin, an activator of adenylate cyclase, raised cAMP to about $23 \mathrm{nM}$ in astrocytes and $2 \mathrm{nM}$ in microglia already after 15 min (data not shown). The impact of DON on the astrocytes was dose-dependent, resulting in a slight increase to $+1 \mathrm{nM}$ at sub- $\mu$ molar level, but a substantial decrease at concentrations above $6 \mu \mathrm{M}$, with $-3 \mathrm{nM}$ at $24 \mu \mathrm{M}$ DON.

To our knowledge, this is the first time that DON-induced changes in the cAMP level of astrocytes are reported. This mode of action might contribute to understand DON neurotoxicity since cAMP activation has an upstream position in pathways connected to stress alleviation or cell death [60]. Since we found that the cAMP levels were increased by exposure to $0.75 \mu \mathrm{M}$ DON and dropped below their physiological level at $6 \mu \mathrm{M} \mathrm{DON}$, it could be possible that the first mechanisms to repair the toxin-mediated stress had been initiated, while higher DON levels suppressed the generation of cAMP, switching the outcome to cell death. 


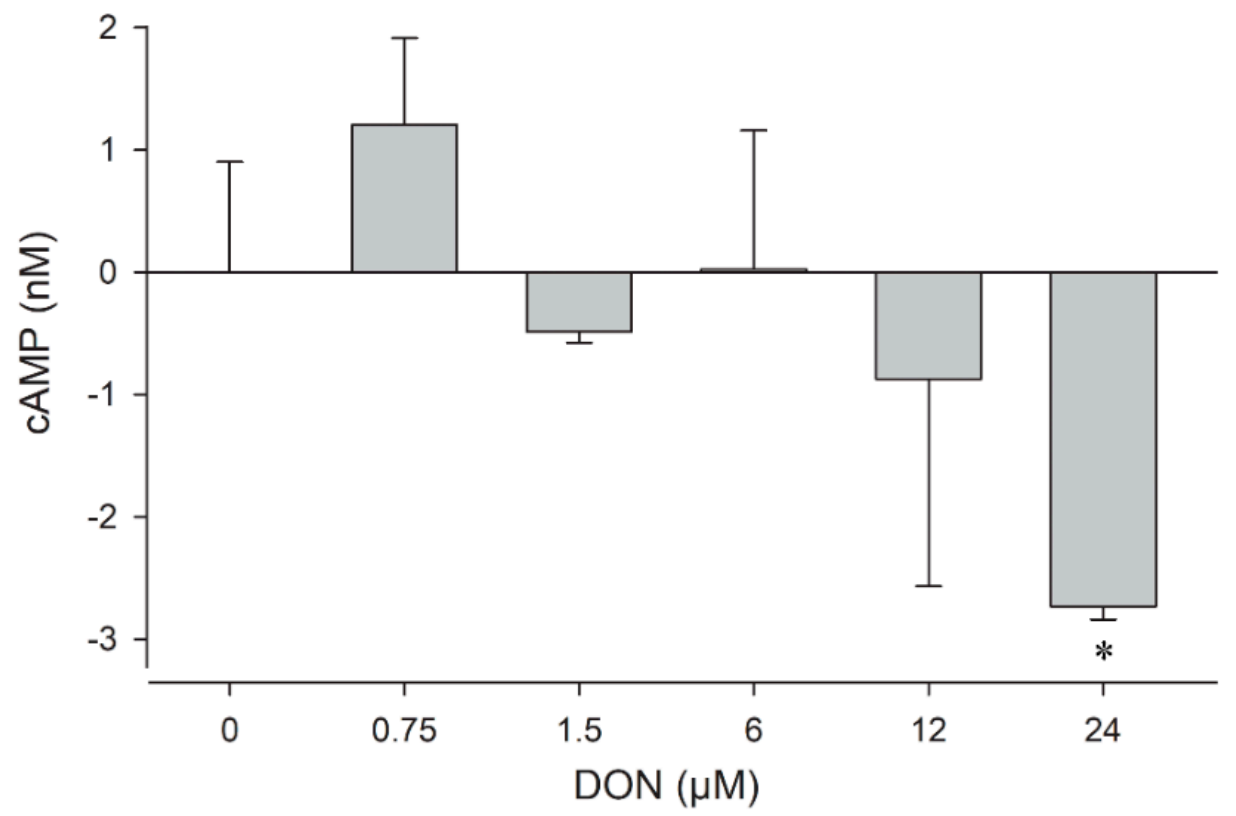

Figure 5. Dose-dependent changes in the cAMP level in murine astrocytes after incubation for $1 \mathrm{~h}$. The data are representative of two independent experiments and are expressed as mean \pm SD of three parallel incubations. Significant differences $(p<0.05)$ determined by Student's t-test are indicated with asterisks $\left(^{*}\right)$.

\subsection{DON Impact on Glial Cells in Primary Hippocampal Cultures}

Cultured primary hippocampal cells, containing astrocytes, microglia, and neurons are a useful model to investigate neuronal vulnerability to toxicants [61]. After their preparation from mouse pup brains, we incubated the hippocampal cells for 15 days, allowing them to interconnect and to fully develop neuronal structures. Exposure to increasing DON levels had a concentration- and time-dependent effect on the astrocyte morphology that became visible by staining of the glial fibrillary acid proteins (GFAP) (Figure 6). Changes could be observed for $6 \mu \mathrm{M}$ DON after $24 \mathrm{~h}$ exposure but were already detectable after $8 \mathrm{~h}$ exposure at higher DON concentrations.

The intermediate filament (type III) GFAP is a fundamental component in the cytoskeleton of astrocytes, shaping cell architecture, providing mechanical strength, regulating filament assembly during mitosis, and helping to support adjacent neurons [62]. There is also evidence for a role in glutamate transporter trafficking and membrane anchoring in astrocytes. The protein is post-translationally modified by phosphorylation at numerous sites, which increases during mitosis. Any disturbance of this process might affect the cell cycle progression in astrocytes, comparably for example, to the changes found in our test using an astrocytes cell culture after $24 \mathrm{~h}$ exposure to 5 and $10 \mu \mathrm{M} \mathrm{DON}$ (Figure 3). In these cultures, the reduction of the astrocytic metabolism was almost maximal for DON at $5 \mu \mathrm{M}$ (Figure 2a) and a negative impact on the astrocytic cAMP concentrations was detected at doses higher than $6 \mu \mathrm{M}$ (Figure 5).

Phosphorylating enzymes such as protein kinase A are often cAMP-dependent and hence influenced by intracellular cAMP-levels. The observed impact of DON at concentration higher than 5 to $6 \mu \mathrm{M}$ in the astrocytes may subsequently affect the GFAP distribution, which is congruent with the morphological changes induced in primary hippocampal cultures by the same DON concentration (Figure 6). Similarly, when primary rat hippocampal cultures were exposed to DON for $48 \mathrm{~h}$ and stained for GFAP in a previous study [35], morphological changes in astrocytes were observable above $10 \mu \mathrm{M}$. Interestingly, changes in the morphology of gliocytes and myenteric neurons in the jejunum had been observed in vivo in rats fed with $0.75 \mathrm{mg} / \mathrm{kg}$ feed [24]. 


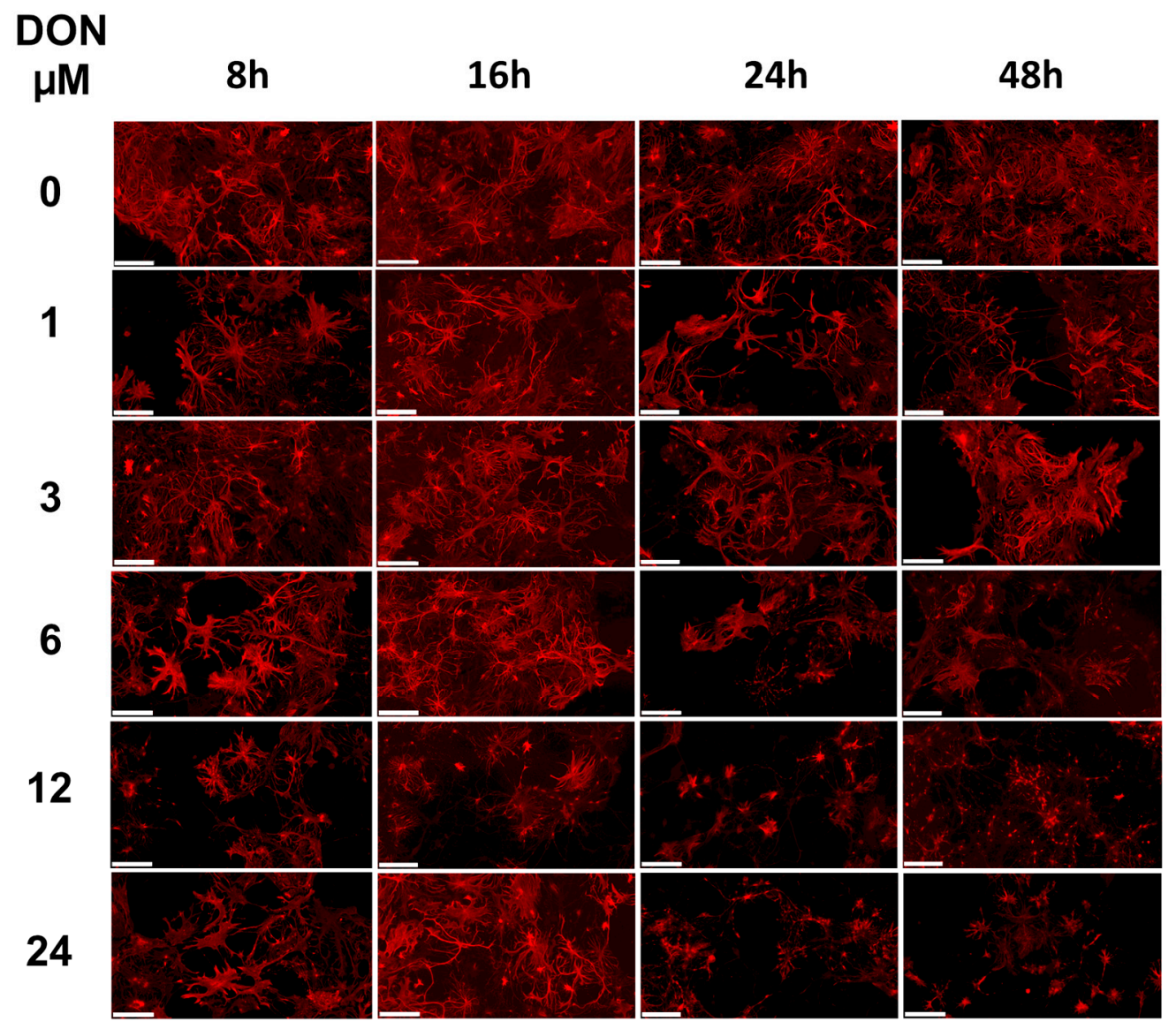

Figure 6. Impact of DON exposure on glial cells in primary hippocampal cultures. Three independent cultures were prepared and analysed for changes in the astrocyte morphology using GFAP staining. Representative images upon treatment with $0,1,3,6,12$, or $24 \mu \mathrm{M}$ DON for $8,16,24$, or $48 \mathrm{~h}$. Scale bars: $100 \mu \mathrm{m}$.

Altogether, our data illustrated the impact of $\mu$ molar DON concentrations on the physiology of astrocytes, both in vitro in a monoculture cell line and ex vivo in primary hippocampal co-cultures.

\subsection{DON Impact on Neurons in Primary Hippocampal Cultures}

Next, we examined changes in the neuron morphology in our mouse primary hippocampal cultures using fluorescence immunostaining of the microtubule-associated protein 2 (MAP2) (Figure 7). The integrity of the neuronal shape is of critical importance for nerve cell functionality, conditioning signal transmission, and synaptic connectivity [63]. Several pathologies, particularly neurodegenerative diseases, are characterised by neuronal loss and by a reduction of the dendritic arborisation $[64,65]$.

The cytoskeleton is an important endogenous determinant of neuronal morphology. Involved in providing stability to the cytoarchitecture of neurons is MAP2, an abundantly occurring, high-molecular weight polypeptide. MAP2 is essential for tubulin polymerisation into microtubules and influences dendritic lengths. Thus, it is an established marker for the somato-dendritic compartment of nerve cells. 

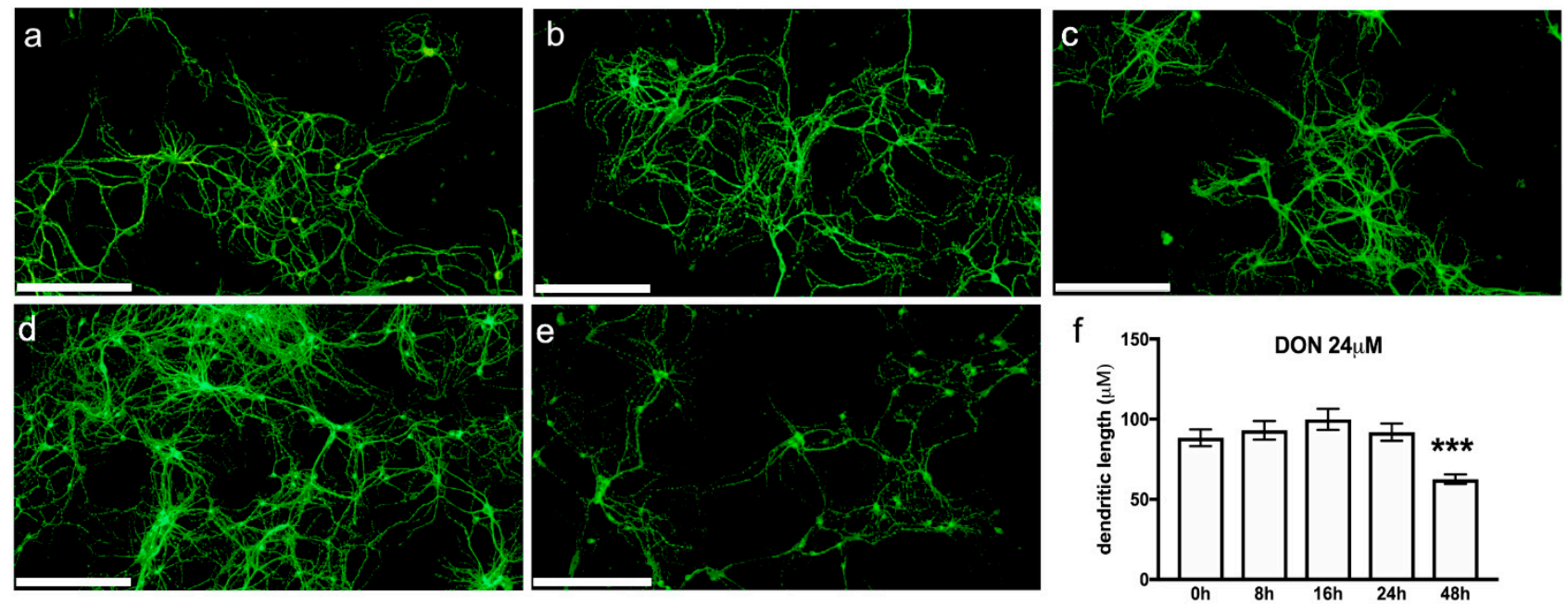

Figure 7. Representative images of murine primary hippocampal cultures: (a) untreated, (b) treated with $24 \mu \mathrm{M}$ DON for $8 \mathrm{~h}$, (c) $16 \mathrm{~h}$, (d) $24 \mathrm{~h}$, or (e) $48 \mathrm{~h}$. Neurons were identified using MAP2 labelling. Scale bars: $250 \mu \mathrm{m}$. (f) Quantification of the dendritic lengths. Data are presented as mean \pm SEM, $n=40-80,{ }^{* * *}$ significant difference $(p<0.001)$ as compared to the other time points.

We examined the impact of $0,1,3,6,12$, or $24 \mu \mathrm{M}$ DON exposure for $8,16,24$ or $48 \mathrm{~h}$ on the neuronal shape (Figure $7 \mathrm{a}-\mathrm{e}$ ) and observed that the dendritic lengths were significantly shortened after $48 \mathrm{~h}$ exposure to $24 \mu \mathrm{M}$ DON (Figure $7 \mathrm{f}$ ). This result gives further evidence of DON's neurotoxic potential. It confirms the impact of chronic low-dose DON exposure, which we previously had detected in neurons of DON-treated mice by using c-fos expression [10].

\section{Conclusions}

The mycotoxin DON has demonstrated a neurotoxic potential in different animal studies. In the present project, we have investigated the underlying mechanisms of action in mouse astrocytes, microglia, and primary hippocampal cultures. We determined that low $\mu$ molar DON concentrations reduced the viability of astrocytes, affected their cell cycle progression, and decreased cAMP levels. In microglia, DON induced cytotoxicity and led to an increased TNF- $\alpha$ secretion. DON exposure affected the morphology of primary neurons by reducing the dendritic arborisation. Taken together, these findings showed that DON interfered with the cellular metabolism/physiology of glial and neuronal cells, which could explain some of the observed neurotoxic in vivo effects.

\section{Materials and Methods}

\subsection{Chemicals}

Deoxynivalenol (DON) (D-0156) was obtained from Sigma-Aldrich (St. Louis, MO, USA). It was dissolved in water for use in the cell exposure studies. Dimethyl sulfoxide (DMSO) and forskolin were from Sigma-Aldrich. Alamar blue, propidium iodide, RNAse A, and DRAQ5 were purchased from ThermoFisher Scientific (Waltham, MA, USA). Dulbecco's Modified Eagle Medium (DMEM), phosphate buffered saline (PBS), trypsin-versene (EDTA) mixture, penicillin-streptomycin mixture, and foetal bovine serum EU standard (FBS) were from Lonza (Verviers, Belgium). The CellTox Green cytotoxicity assay and cAMP-Glo assay were bought from Promega (Madison, WI, USA). BD BioCoat Cellware poly-L-lysine $12 \mathrm{~mm}$ coverslips and the TNF- $\alpha$ ELISA were obtained from BD Biosciences (Bedford, MA, USA). The IL-1 $\beta$ ELISA was from R \&D Systems (Minneapolis, MN, USA).

\subsection{Cell Culture Conditions}

Murine C8-B4 microglia cells (ATCC CRL-2540; monocytes from cerebellum of C57BL/ 6 mice (Mus musculus) and C8-D1A astrocytes (ATCC CRL-2541; astrocyte type I clone 
from C57BL/ 6 mouse cerebellum) were obtained from American Type Culture Collection (ATCC, Manassas, VA, USA) and grown in DMEM-supplemented with 10\% FBS and 1\% penicillin/streptomycin. The microglia and astrocytes were cultured at $37{ }^{\circ} \mathrm{C}$ under $5 \%$ $\mathrm{CO}_{2}$ in a humidified incubator (NuAire, Plymouth, MN, USA) and sub-cultivated by trypsination once/twice per week in a 1:5/1:10 split ratio, respectively. They were allowed to grow as monolayers in $75 \mathrm{~cm}^{2}$ cell culture flasks with filter screwcaps (Techno Plastic Products, Trasadingen, Switzerland) until $80-100 \%$ confluence was reached. The microglia and astrocytes were plated at $90,000 / \mathrm{cm}^{2}$ and $45,000 / \mathrm{cm}^{2}$, respectively, $24 \mathrm{~h}$ prior to the test, which resulted in approximately $90 \%$ confluence at the day of exposure as observed by light microscopy (Leica DMIL, Solms, Germany). The cell culture medium was refreshed before performing the exposure test.

\subsection{Metabolic Activity}

Metabolic activity of astrocytes and microglia was measured after exposure to 0.8 , $1.6,3.1,6.3,12.5$, and $25 \mu \mathrm{M}$ DON for $24 \mathrm{~h}$ using the Alamar blue assay according to the manufacturer's protocol (ThermoFisher Scientific). The dark blue oxidised form of Alamar Blue (resazurin) is reduced to a highly fluorescent form (resorufin) by mitochondrial or cytoplasmatic enzymes. The fluorescence (Ex: $555 \mathrm{~nm}, \mathrm{Em}: 585 \mathrm{~nm}$ ) was quantified using the Spectramax i3x plate reader (Molecular Devices, San Jose, CA, USA). The measured fluorescence intensity is proportional to the number of viable cells and a measurement of the metabolic fitness of the cells [40].

\subsection{Cytotoxicity}

Cytotoxic effects of $\operatorname{DON}(0.8,1.6,3.1,6.3,12.5$, and $25 \mu \mathrm{M})$ in astrocytes and microglia were analysed after $24 \mathrm{~h}$ exposure with CellTox ${ }^{\mathrm{TM}}$ Green Dye (1:2000). The dye was added to the cells as described by the manufacturer, and fluorescence signals (Em: $485 \mathrm{~nm} / \mathrm{Em}$ : $520 \mathrm{~nm}$ ) were quantified with a Spectramax i3x plate reader using the well scan function by reading 32 different points/well in all wells. The cytotoxicity data were normalised by the total cell numbers, which were determined by staining with the nuclear stain DRAQ5 (1:500, $30 \mathrm{~min}$ ) and counting with the Spectramax i3x plate reader equipped with a microscopic module (MiniMax300imaging cytometer, Molecular Devices), Ex: 625 nm, Em: 713 nm.

\subsection{Expression of Cytokines}

TNF- $\alpha$ secretion was measured in the supernatants of astrocytes and microglia exposed to $0.38,0.75,1.5,3$ and $6 \mu \mathrm{M}$ DON for $24 \mathrm{~h}$. After centrifugation $(500 \times g, 10 \mathrm{~min})$ to remove cell debris, TNF- $\alpha$ was quantified by enzyme-linked immunosorbent (ELISA) as instructed by the manufacturer using the Spectramax i3x plate reader. IL- $1 \beta$ levels in the cell supernatants were measured by ELISA following the manufacturer's guidelines. Additionally, IL-1 $\beta$ was measured in microglia cells that had been pre-incubated with 0.05 or $0.1 \mathrm{ng} / \mathrm{mL}$ LPS for $3 \mathrm{~h}$ and exposed to 0.75 or $1.5 \mu \mathrm{M} \mathrm{DON}$ for $24 \mathrm{~h}$.

\subsection{Cell Cycle Analysis}

For cell cycle analysis, astrocytes and microglia were exposed to $1,2.5,5$, and $10 \mu \mathrm{M}$ DON for $24 \mathrm{~h}$, washed with PBS and fixed with ice-cold $70 \%$ ethanol overnight at $-20{ }^{\circ} \mathrm{C}$. The cells were then washed with PBS, incubated with propidium iodide $(10 \mu \mathrm{g} / \mathrm{mL}) / \mathrm{RNase}$ A $(100 \mu \mathrm{g} / \mathrm{mL})$ in PBS for $30 \mathrm{~min}$ at $37^{\circ} \mathrm{C}$ before analysis by flow cytometry (Accuri C6; BD Biosciences). Single cells were gated and a minimum of 10,000 cells acquired and analysed. Data acquired were analysed by Accuri CFlow Plus software (version 1.0.227.4; BD Biosciences).

\subsection{Determination of cAMP Levels}

Astrocytes and microglia were exposed to $0.75,1.5,6,12$ and $24 \mu \mathrm{M} \mathrm{DON}$ for $1 \mathrm{~h}$, and intracellular cAMP concentrations were measured using the cAMP-Glo assay according to 
the manufacturer's guidelines (Promega) using the Spectramax i3x plate reader. The cAMP agonist forskolin ( $4 \mu \mathrm{M} ; 15$ min exposure) was used as positive control.

\subsection{Primary Hippocampal Cultures from Mouse Pups}

Primary hippocampal cell cultures were prepared as previously described [66]. Briefly, P0-P3 mice pups from C57BL/6J:129SvPas (50:50) mice were decapitated. Hippocampi were dissected and digested with papain $(20 \mathrm{U} / \mathrm{mL}$, Worthington Biochemical Corp., Lakewood, $\mathrm{NJ}$, USA). The cells were plated (8-10 $\times 10^{4}$ cells/well) on poly-L-lysine-coated coverslips in 24-well plates. Cultures were maintained for 15 days in vitro (DIV) with half of the medium (Neurobasal A medium: $2 \mathrm{mM}$ glutamax, $0.5 \mathrm{mM}$ glutamine, penicillin/streptomycin, supplemented with $2 \%$ B27) (GIBCO, Loughborough, UK) changed every 5 to 7 days. The cells were incubated for $8 \mathrm{~h}, 16 \mathrm{~h}, 24 \mathrm{~h}$, or $48 \mathrm{~h}$ with $0,1,3,6,12$, or $24 \mu \mathrm{M} \mathrm{DON}$, washed in cold $0.1 \mathrm{M}$, pH 7.4 PBS and fixed with $4 \%$ paraformaldehyde (32\% diluted to $4 \%$ before use; ThermoFisher Scientific). The coverslips with fixated cells were washed three times with cold PBS and kept at $4{ }^{\circ} \mathrm{C}$ until processing.

\subsection{Determination of Neural and Glial Markers by Immunofluorescence}

Primary hippocampal cultures were incubated in PBST blocking solution (PBS with $0.2 \%$ Tween 20 and 5\% normal goat serum; Sigma-Aldrich) for one hour at room temperature (RT) $\left(20-22{ }^{\circ} \mathrm{C}\right)$, and then overnight at $4{ }^{\circ} \mathrm{C}$ in blocking solution with mouse anti-microtubule-associated protein 2 (MAP2, (1:1000; Sigma-Aldrich) and rabbit anti-glial fibrillate acid protein (GFAP, 1:5000; DakoCytomation, Glostrup, Denmark) primary antibodies. The cells were washed three times in PBST and incubated for $2 \mathrm{~h}$ at RT with goat anti-mouse antibodies coupled to AlexaFluor 647 (1:500; A21240, Molecular Probes; Eugene, OR, USA) and goat anti-rabbit antibodies coupled to AlexaFluor 594 (1:2000; A11012, Molecular Probes). After three washes in PBST and incubation in PBST for $2 \mathrm{~h}$ at RT, nuclei were stained with 4',6-diamidino-2-phenylindole dihydrochloride (DAPI); ThermoFisher Scientific) $(1 \mu \mathrm{g} / \mathrm{mL}$ in PBS) for $5 \mathrm{~min}$ in the dark. After the removal of the staining solution, the cells were washed in PBS, mounted with ProLong ${ }^{\text {TM }}$ Gold Antifade mounting medium (Molecular Probes) and kept at $-20^{\circ}$ protected from light until imaging. Images were acquired using the slide scanner NanoZoomer 2 HT with fluorescence module L11600-21 (Hamamatsu Photonics, Hamamatsu City, Japan). Single RGB colour acquisition was made in the epifluorescence mode with the time delay integration 3-chip camera equipped with a filter-set optimised for DAPI, tetramethylrhodamine and cyanine- 5 detection. The acquisition was performed using a dry 20x objective (NA: 0.75). The 40x resolution was achieved with a lens converter. The latter mode used the full capacity of the camera (resolution: $0.23 \mu \mathrm{m} / \mathrm{pixel})$.

\subsection{Image Analysis}

Dendritic lengths were measured on images of neurons labelled with MAP2 (randomly selected from three independent cultures) using the NeuronJ plugin from the Image J package Fiji (Available online: https: / /imagej.net/software/fiji/ (accessed on 13 December 2021), which allows semiautomatic tracing and measurement of neurites [67].

\subsection{Statistical Analysis}

Data of the cellular assays were analysed by using Sigma Plot version 12.0 (Alfasoft AS, Lillestrøm, Norway). Statistical significance $(p<0.05)$ was assessed using 1-way-ANOVA, followed by the Holm-Sidak post-test. When data failed the equal variance test, ANOVA could not be used. Instead, the Student's t-test was performed for comparing the control group to the treated group. Standard error of the mean (SEM) was used for results of the cell line assays, where the mean of several independent experiments with three or more replicates were shown. Standard derivation (SD) was used when one representative experiment with three or more replicates was shown. Statistical analysis of dendritic lengths was performed with Graph-Pad Prism V7 (Available online: https:/ / www.graphpad.com/ 
(accessed on 13 December 2021) using the non-parametric Kruskall-Wallis test followed by Dunn's post hoc comparison.

Author Contributions: Conceptualization, C.K.F. and D.M.; methodology, D.M. and A.S.; formal analysis, A.S., F.P., M.G. and D.M.; resources, C.K.F. and D.M.; data curation, A.S., C.K.F. and D.M.; writing-original draft preparation, C.K.F.; writing-review and editing, C.K.F., A.S. and D.M.; visualization, C.K.F., A.S. and D.M.; supervision, C.K.F. and D.M.; project administration, C.K.F. and D.M.; funding acquisition, C.K.F. and D.M. All authors have read and agreed to the published version of the manuscript.

Funding: This research was funded through the bilateral PHC AURORA-program by the Research Council of Norway (Grant Number NFR255406) and Campus France, and in addition the CNRS, the University of Strasbourg and the Norwegian Veterinary Institute.

Institutional Review Board Statement: Not applicable.

Informed Consent Statement: Not applicable.

Data Availability Statement: The data sets generated during the current study are available from the authors upon request.

Acknowledgments: The authors would like to thank Hege Divon at the Norwegian Veterinary Institute (NVI) for funding the consumables and chemical analyses used in the study through FUNtox, a strategic institute program on Fungi and Mycotoxins in a "One Health" perspective.

Conflicts of Interest: The authors declare no conflict of interest. The funders had no role in the design of the study; in the collection, analyses, or interpretation of data; in the writing of the manuscript, or in the decision to publish the results.

\section{References}

1. Mishra, S.; Srivastava, S.; Dewangan, J.; Divakar, A.; Kumar Rath, S. Global occurrence of deoxynivalenol in food commodities and exposure risk assessment in humans in the last decade: A survey. Crit. Rev. Food Sci. Nutr. 2020, 60, 1346-1374. [CrossRef]

2. EU Commission Regulation (EC) No 1881/2006 of 19 December 2006 Setting Maximum Levels for Certain Contaminants in Foodstuffs. Available online: https:/ / eur-lex.europa.eu/legal-content/EN/ALL/?uri=celex\%3A32006R1881 (accessed on 22 June 2021).

3. EU Commission Recommendation of 17 August 2006 on the Presence of Deoxynivalenol, Zearalenone, Ochratoxin A, T-2 and HT-2 and Fumonisins in Products Intended for Animal Feeding. Available online: http:/ / eur-lex.europa.eu/legal-content/EN/ TXT / ?qid=1440504898051\&uri=CELEX:32006H0576 (accessed on 22 June 2021).

4. EFSA. Risks to human and animal health related to the presence of deoxynivalenol and its acetylated and modified forms in food and feed. EFSA J. 2017, 15, 4718 .

5. Vidal, A.; Bouzaghnane, N.; De Saeger, S.; De Boevre, M. Human mycotoxin biomonitoring: Conclusive remarks on direct or indirect assessment of urinary deoxynivalenol. Toxins 2020, 12, 139. [CrossRef]

6. $\quad$ Deng, Y.; You, L.; Nepovimova, E.; Wang, X.; Musilek, K.; Wu, Q.; Wu, W.; Kuca, K. Biomarkers of deoxynivalenol (DON) and its modified form DON-3-glucoside (DON-3G) in humans. Trends Food Sci. Tech. 2021, 110, 551-558. [CrossRef]

7. Sundheim, L.; Lillegaard, I.T.; Fæste, C.K.; Brantsæter, A.L.; Brodal, G.; Eriksen, G.S. Deoxynivalenol exposure in Norway, risk assessments for different human age groups. Toxins 2017, 9, 46. [CrossRef] [PubMed]

8. Martins, C.; Torres, D.; Lopes, C.; Correia, D.; Goios, A.; Assunção, R.; Alvito, P.; Vidal, A.; De Boevre, M.; De Saeger, S.; et al. Deoxynivalenol exposure assessment through a modelling approach of food intake and biomonitoring data-A contribution to the risk assessment of an enteropathogenic mycotoxin. Food Res. Int. 2021, 140, 109863. [CrossRef] [PubMed]

9. Tardivel, C.; Airault, C.; Djelloul, M.; Guillebaud, F.; Barbouche, R.; Troadec, J.D.; Gaigé, S.; Dallaporta, M. The foodborne mycotoxin deoxynivalenol induces low-grade inflammation in mice in the absence of observed-adverse effects. Toxicol. Lett. 2015, 232, 601-611. [CrossRef] [PubMed]

10. Fæste, C.K.; Pierre, F.; Ivanova, L.; Sayyari, A.; Massotte, D. Behavioural and metabolomic changes from chronic dietary exposure to low-level deoxynivalenol reveal impact on mouse well-being. Arch. Toxicol. 2019, 93, 2087-2102. [CrossRef] [PubMed]

11. Csikós, V.; Varró, P.; Bódi, V.; Oláh, S.; Világi, I.; Dobolyi, A. The mycotoxin deoxynivalenol activates GABAergic neurons in the reward system and inhibits feeding and maternal behaviours. Arch. Toxicol. 2020, 94, 3297-3313. [CrossRef] [PubMed]

12. Nordgreen, J.; Edwards, S.A.; Boyle, L.A.; Bolhuis, J.E.; Veit, C.; Sayyari, A.; Marin, D.E.; Dimitrov, I.; Janczak, A.M.; Valros, A. A proposed role for pro-inflammatory cytokines in damaging behavior in pigs. Front. Vet. Sci. 2020, 7, 646. [CrossRef] [PubMed]

13. Yegani, M.; Chowdhury, S.R.; Oinas, N.; MacDonald, E.J.; Smith, T.K. Effects of feeding grains naturally contaminated with Fusarium mycotoxins on brain regional neurochemistry of laying hens, turkey poults, and broiler breeder hens. Poult. Sci. 2006, 85, 2117-2123. [CrossRef] 
14. Janković-Tomanić, M.; Petković, B.; Todorović, D.; Vranković, J.; Perić-Mataruga, V. Physiological and behavioral effects of the mycotoxin deoxynivalenol in Tenebrio molitor larvae. J. Stored Prod. Res. 2019, 83, 236-242. [CrossRef]

15. Behrens, M.; Hüwel, S.; Galla, H.J.; Humpf, H.U. Blood-brain barrier effects of the Fusarium mycotoxins deoxynivalenol, 3-acetyldeoxynivalenol, and moniliformin and their transfer to the brain. PLoS ONE 2015, 10, e0143640. [CrossRef] [PubMed]

16. Bonnet, M.S.; Roux, J.; Mounien, L.; Dallaporta, M.; Troadec, J.D. Advances in deoxynivalenol toxicity mechanisms: The brain as a target. Toxins 2012, 4, 1120-1138. [CrossRef] [PubMed]

17. Al-Hazmi, M.A.; Waggas, A.M. Neurophysiological and behavioral effects of mycotoxin deoxynivalenol and fumonisin. Afri. Microbiol. Res. 2013, 7, 1371-1377.

18. Fitzpatrick, D.W.; Boyd, K.E.; Wilson, L.M.; Wilson, J.R. Effect of the trichothecene deoxynivalenol on brain biogenic monoamines concentrations in rats and chickens. J. Environ. Sci. Health B 1988, 23, 159-170. [CrossRef] [PubMed]

19. Prelusky, D.B.; Yeung, J.M.; Thompson, B.K.; Trenholm, H.I. Effect of deoxynivalenol on neurotransmitters in discrete regions of swine brain. Arch. Environ. Contam. Toxicol. 1992, 22, 36-40. [CrossRef] [PubMed]

20. Girardet, C.; Bonnet, M.S.; Jdir, R.; Sadoud, M.; Thirion, S.; Tardivel, C.; Roux, J.; Lebrun, B.; Mounien, L.; Trouslard, J.; et al. Central inflammation and sickness-like behavior induced by the food contaminant deoxynivalenol: A PGE2-independent mechanism. Toxicol. Sci. 2011, 124, 179-191. [CrossRef]

21. Girardet, C.; Bonnet, M.S.; Jdir, R.; Sadoud, M.; Thirion, S.; Tardivel, C.; Roux, J.; Lebrun, B.; Wanaverbecq, N.; Mounien, L.; et al The food-contaminant deoxynivalenol modifies eating by targeting anorexigenic neurocircuitry. PLoS ONE 2011, 6, e26134. [CrossRef]

22. Gaigé, S.; Bonnet, M.S.; Tardivel, C.; Pinton, P.; Trouslard, J.; Jean, A.; Guzylack, L.; Troadec, J.D.; Dallaporta, M. c-Fos immunoreactivity in the pig brain following deoxynivalenol intoxication: Focus on NUCB2/nesfatin-1 expressing neurons. Neuro Toxicol. 2013, 34, 135-149. [CrossRef]

23. Wang, X.; Chen, X.; Cao, L.; Zhu, L.; Zhang, Y.; Chu, X.; Zhu, D.; Ur Rahman, S.; Peng, C.; Feng, S.; et al. Mechanism of deoxynivalenol-induced neurotoxicity in weaned piglets is linked to lipid peroxidation, dampened neurotransmitter levels, and interference with calcium signaling. Ecotoxicol. Environ. Saf. 2020, 194, 110382. [CrossRef]

24. Rissato, D.F.; de Santi Rampazzo, A.P.; Borges, S.C.; Sousa, F.C.; Busso, C.; Buttow, N.C.; Natali, M.R.M. Chronic ingestion of deoxynivalenol-contaminated diet dose-dependently decreases the area of myenteric neurons and gliocytes of rats. Neurogastroenterol. Motil. 2020, 32, e13770. [CrossRef]

25. Ivanova, L.; Fæste, C.K.; Solhaug, A. Role of P-glycoprotein in deoxynivalenol-mediated in vitro toxicity. Toxicol. Lett. 2018, 284, 21-28. [CrossRef]

26. Pestka, J.J. Deoxynivalenol: Toxicity, mechanisms and animal health risks. Anim. Feed Sci. Technol. 2007, 137, 283-298. [CrossRef]

27. Pan, X.; Whitten, D.A.; Wu, M.; Chan, C.; Wilkerson, C.G.; Pestka, J.J. Global protein phosphorylation dynamics during deoxynivalenol-induced ribotoxic stress response in the macrophage. Toxicol. Appl. Pharmacol. 2013, 268, 201-211. [CrossRef]

28. Wang, X.; Xu, W.; Fan, M.; Meng, T.; Chen, X.; Jiang, Y.; Zhu, D.; Hu, W.; Gong, J.; Feng, S.; et al. Deoxynivalenol induces apoptosis in PC12 cells via the mitochondrial pathway. Environ. Toxicol. Pharmacol. 2016, 43, 193-202. [CrossRef]

29. Li, D.; Ye, Y.; Lin, S.; Deng, L.; Fan, X.; Zhang, Y.; Deng, X.; Li, Y.; Yan, H.; Ma, Y. Evaluation of deoxynivalenol-induced toxic effects on DF-1 cells in vitro: Cell-cycle arrest, oxidative stress, and apoptosis. Environ. Toxicol. Pharmacol. 2014, 37, 141-149. [CrossRef] [PubMed]

30. Döll, S.; Schrickx, J.A.; Dänicke, S.; Fink-Gremmels, J. Deoxynivalenol-induced cytotoxicity, cytokines and related genes in unstimulated or lipopolysaccharide stimulated primary porcine macrophages. Toxicol. Lett. 2009, 184, 97-106. [CrossRef] [PubMed]

31. Solhaug, A.; Karlsøen, L.M.; Holme, J.A.; Kristoffersen, A.B.; Eriksen, G.S. Immunomodulatory effects of individual and combined mycotoxins in the THP-1 cell line. Toxicol. In Vitro 2016, 36, 120-132. [CrossRef] [PubMed]

32. Wang, X.; Liu, Q.; Ihsan, A.; Huang, L.; Dai, M.; Hao, H.; Cheng, G.; Liu, Z.; Wang, Y.; Yuan, Z. JAK/STAT pathway plays a critical role in the proinflammatory gene expression and apoptosis of RAW264.7 cells induced by trichothecenes as DON and T-2 toxin. Toxicol. Sci. 2012, 127, 412-424. [CrossRef] [PubMed]

33. He, K.; Zhou, H.R.; Pestka, J.J. Mechanisms for ribotoxin-induced ribosomal RNA cleavage. Toxicol. Appl. Pharmacol. 2012, 265, 10-18. [CrossRef] [PubMed]

34. Waché, Y.J.; Hbabi-Haddioui, L.; Guzylack-Piriou, L.; Belkhelfa, H.; Roques, C.; Oswald, I.P. The mycotoxin deoxynivalenol inhibits the cell surface expression of activation markers in human macrophages. Toxicology 2009, 262, 239-244. [CrossRef] [PubMed]

35. Razafimanjato, H.; Benzaria, A.; Taïeb, N.; Guo, X.J.; Vidal, N.; Di Scala, C.; Varini, K.; Maresca, M. The ribotoxin deoxynivalenol affects the viability and functions of glial cells. Glia 2011, 59, 1672-1683. [CrossRef] [PubMed]

36. Pestka, J.J.; Islam, Z.; Amuzie, C.J. Immunochemical assessment of deoxynivalenol tissue distribution following oral exposure in the mouse. Toxicol. Lett. 2008, 178, 83-87. [CrossRef] [PubMed]

37. Maresca, M. From the gut to the brain: Journey and pathophysiological effects of the food-associated trichothecene mycotoxin deoxynivalenol. Toxins 2013, 5, 784-820. [CrossRef] [PubMed]

38. Liu, B.; Teschemacher, A.G.; Kasparov, S. Neuroprotective potential of astroglia. J. Neurosci. Res. 2017, 95, 2126-2139. [CrossRef]

39. Zhang, J.; You, L.; Wu, W.; Wang, X.; Chrienova, Z.; Nepovimova, E.; Wu, Q.; Kuca, K. The neurotoxicity of trichothecenes T-2 toxin and deoxynivalenol (DON): Current status and future perspectives. Food Chem. Toxicol. 2020, 145, 111676. [CrossRef] 
40. Rampersad, S.N. Multiple applications of Alamar Blue as an indicator of metabolic function and cellular health in cell viability bioassays. Sensors 2012, 12, 12347-12360. [CrossRef]

41. Kouadio, J.H.; Mobio, T.A.; Baudrimont, I.; Moukha, S.; Dano, S.D.; Creppy, E.E. Comparative study of cytotoxicity and oxidative stress induced by deoxynivalenol, zearalenone or fumonisin B1 in human intestinal cell line Caco-2. Toxicology 2005, $213,56-65$. [CrossRef] [PubMed]

42. Nasri, T.; Bosch, R.R.; Ten Voorde, S.; Fink-Gremmels, J. Differential induction of apoptosis by type A and B trichothecenes in Jurkat T-lymphocytes. Toxicol. In Vitro 2006, 20, 832-840. [CrossRef]

43. Maresca, M.; Mahfoud, R.; Garmy, N.; Fantini, J. The mycotoxin deoxynivalenol affects nutrient absorption in human intestinal epithelial cells. J. Nutr. 2002, 132, 2723-2731. [CrossRef]

44. Simpson, I.A.; Carruthers, A.; Vannucci, S.J. Supply and demand in cerebral energy metabolism: The role of nutrient transporters. J. Cerebr. Blood Flow Metabol. 2007, 27, 1766-1791. [CrossRef]

45. Monnet-Tschudi, F.; Zurich, M.G.; Honegger, P. Neurotoxicant-induced inflammatory response in three-dimensional brain cell cultures. Hum. Exp. Toxicol. 2007, 26, 339-346. [CrossRef]

46. Kreutzberg, G.W. Microglia: A sensor for pathological events in the CNS. Trends Neurosci. 1996, 19, 312-318. [CrossRef]

47. Ji, G.E.; Park, S.Y.; Wong, S.S.; Pestka, J.J. Modulation of nitric oxide, hydrogen peroxide and cytokine production in a clonal macrophage model by the trichothecene vomitoxin (deoxynivalenol). Toxicology 1998, 125, 203-214. [PubMed]

48. Lukas, J.; Lukas, C.; Bartek, J. Mammalian cell cycle checkpoints: Signalling pathways and their organization in space and time. DNA Repair 2004, 3, 997-1007. [CrossRef]

49. Marzocco, S.; Russo, R.; Bianco, G.; Autore, G.; Severino, L. Pro-apoptotic effects of nivalenol and deoxynivalenol trichothecenes in J774A. 1 murine macrophages. Toxicol. Lett. 2009, 189, 21-26. [CrossRef] [PubMed]

50. Bianco, G.; Fontanella, B.; Severino, L.; Quaroni, A.; Autore, G.; Marzocco, S. Nivalenol and deoxynivalenol affect rat intestinal epithelial cells: A concentration related study. PLoS ONE 2012, 7, e52051. [CrossRef]

51. Tiemann, U.; Viergutz, T.; Jonas, L.; Schneider, F. Influence of the mycotoxins $\alpha$-and $\beta$-zearalenol and deoxynivalenol on the cell cycle of cultured porcine endometrial cells. Reprod. Toxicol. 2003, 17, 209-218. [CrossRef]

52. Juan-García, A.; Taroncher, M.; Font, G.; Ruiz, M.J. Micronucleus induction and cell cycle alterations produced by deoxynivalenol and its acetylated derivatives in individual and combined exposure on HepG2 cells. Food Chem. Toxicol. 2018, 118, 719-725. [CrossRef]

53. Diesing, A.K.; Nossol, C.; Dänicke, S.; Walk, N.; Post, A.; Kahlert, S.; Rothkötter, H.-J.; Kluess, J. Vulnerability of polarised intestinal porcine epithelial cells to mycotoxin deoxynivalenol depends on the route of application. PLoS ONE 2011, 6, e17472 [CrossRef] [PubMed]

54. Yang, H.; Chung, D.H.; Kim, Y.B.; Choi, Y.H.; Moon, Y. Ribotoxic mycotoxin deoxynivalenol induces G2/M cell cycle arrest via p21Cip/WAF1 mRNA stabilization in human epithelial cells. Toxicology 2008, 243, 145-154. [CrossRef] [PubMed]

55. He, Y.; Yin, X.; Dong, J.; Yang, Q.; Wu, Y.; Gong, Z. Transcriptome Analysis of Caco-2 Cells upon the exposure of mycotoxin deoxynivalenol and its acetylated derivatives. Toxins 2021, 13, 167. [CrossRef] [PubMed]

56. Stanic, A.; Uhlig, S.; Solhaug, A.; Rise, F.; Wilkins, A.L.; Miles, C.O. Nucleophilic addition of thiols to deoxynivalenol. J. Agric. Food Chem. 2015, 63, 7556-7566. [CrossRef] [PubMed]

57. Slotkin, T.A.; Seidler, F.J. Comparative developmental neurotoxicity of organophosphates in vivo: Transcriptional responses of pathways for brain cell development, cell signaling, cytotoxicity and neurotransmitter systems. Brain Res. Bull. 2007, 72, 232-274. [CrossRef]

58. Adornetto, A.; Pagliara, V.; Di Renzo, G.; Arcone, R. Polychlorinated biphenyls impair dibutyryl cAMP-induced astrocytic differentiation in rat C6 glial cell line. FEBS Open Biol. 2013, 3, 459-466. [CrossRef]

59. Pahan, K.; Namboodiri, A.M.; Sheikh, F.G.; Smith, B.T.; Singh, I. Increasing cAMP attenuates induction of inducible nitric-oxide synthase in rat primary astrocytes. J. Biol. Chem. 1997, 272, 7786-7791. [CrossRef]

60. Karaçay, B.; Li, G.; Pantazis, N.J.; Bonthius, D.J. Stimulation of the cAMP pathway protects cultured cerebellar granule neurons against alcohol-induced cell death by activating the neuronal nitric oxide synthase (nNOS) gene. Brain Res. 2007, 1143, 34-45. [CrossRef]

61. Ray, J.; Peterson, D.A.; Schinstine, M.; Gage, F.H. Proliferation, differentiation, and long-term culture of primary hippocampal neurons. Proc. Natl. Acad. Sci. USA 1993, 90, 3602-3606. [CrossRef]

62. McKeon, A.; Benarroch, E.E. Glial fibrillary acid protein: Functions and involvement in disease. Neurology 2018, 90, 925-930. [CrossRef]

63. Caceres, A.; Banker, G.; Steward, O.; Binder, L.; Payne, M. MAP2 is localized to the dendrites of hippocampal neurons which develop in culture. Dev. Brain Res. 1984, 13, 314-318. [CrossRef]

64. Furlong, R.M.; O'Keeffe, G.W.; O'Neill, C.; Sullivan, A.M. Alterations in $\alpha$-synuclein and PINK1 expression reduce neurite length and induce mitochondrial fission and Golgi fragmentation in midbrain neurons. Neurosci. Lett. 2020, 720, 134777. [CrossRef]

65. Burak, K.; Lamoureux, L.; Boese, A.; Majer, A.; Saba, R.; Niu, Y.; Frost, K.; Booth, S.A. MicroRNA-16 targets mRNA involved in neurite extension and branching in hippocampal neurons during presymptomatic prion disease. Neurobiol. Dis. 2018, 112, 1-13. [CrossRef] 
66. Derouiche, L.; Ugur, M.; Pierre, F.; Mann, A.; Doridot, S.; Ory, S.; Schulz, S.; Massotte, D. Heteromerization of endogenous mu and delta opioid receptors tunes mu opioid receptor signaling and trafficking. bioRxiv 2018, 455147. [CrossRef]

67. Pemberton, K.; Mersman, B.; Xu, F. Using ImageJ to assess neurite outgrowth in mammalian cell cultures: Research data quantification exercises in undergraduate neuroscience lab. J. Undergrad. Neurosci. Educ. 2018, 16, A186-A194. [PubMed] 